\title{
Community Based Forestry in Nepal: Status, Issues and Lessons Learned
}

\author{
Bhoj Raj Pathak ${ }^{1}$, Xie Yi ${ }^{1}$, Radhika Bohara²
}

\author{
${ }^{1}$ School of Economics and Management, Beijing Forestry University, No35, Qinghua East Road, Haidian District, \\ Beijing, Peoples Republic of china, Post Code -100083 \\ ${ }^{2}$ Department of Forest, Babarmahal, Kathmandu, Nepal, Post Code-44600
}

\begin{abstract}
Community Based Forest Management (CBFM) is a system of managing forest by the participation of local community for the mutual benefit of forest and local people. However, the level of participation may be varied according to the modalities and tenure arrangements. Nepal has been implementing CBFM approach for the forest through differently named programs since 1976, with the formulation of National Forestry Plan, 1976. Recently, six different modalities of forest management are categorized as CBFM that covers about 2.3 million hectare forest that is $38.5 \%$ of total forest in the country, and involved more than 3.8 million households. This vast number of households benefited has also brought special attention on further development and expansion of community based forest management modalities in Nepal. Moreover, its piloting experience on CBFM, Nepal appears at the front position in implementing CBFM program in the international arena. To grab this achievement it has gone through many ups and downs. Behind its success stories it has faced many issues with lots of learning and experience. In this connection, this paper has tries to explore the current status of various CBFM modalities in Nepal retrospectively with the experience from more than 3 decades of policy formulation and implementation. Moreover, this paper also strives to illustrate the lessons learned, related issues and the recent initiatives on CBFM practice in Nepal, which may benefit the policy makers and practitioners interested in community based forestry. Moreover, this paper has highlighted that only one type of CBFM model is not enough to address the need of different category people of diverse locality, for which policy reforms and revision of relevant guidelines are crucial according to the changing context and lesson learns.
\end{abstract}

Keywords: Community Based Forest management, People’s participation, Policy reform, Nepal.

\section{Introduction}

Community based forest management (CBFM) is not a new concept as it is under implementation under different names with varied tenure arrangements in different countries for several decades now. It was found that CBFM been practiced by local communities from the ancient times; but only came into the sight of donors and national governments during the late 1970s (Roe et al 2009). In Nepal, the National Forestry Plan of 1976 established a policy foundation for the first time to facilitate the participation of local communities in forest management with technical assistance from the Department of Forest. Succeeding was an extensive strategy for 21 years called "Master Plan for Forestry Sector (MPFS)" (1989) prepared with imperatives such as sustainable utilization of forest resources, peoples participation in decision making and benefit sharing, and socio-economic growth, which ultimately mainstreamed the concept of CBFM in Nepal.

\begin{abstract}
Basically, the CBFM is a system of managing forests by local community people for the mutual benefits of the forests as well as their livelihood. The level of involvement of the local people may be varied according to the modalities and tenure arrangements. In recent years, community CBFM has become more popular amongst the developing countries (Maraseni et al., 2014). Nevertheless, the concept of CBFM is equally popular amongst developed countries. For instance, in countries such as France and Switzerland where significant forest areas are managed through some form of communal management rights (FAO, 2010; cited in FAO, 2016). CBFM approach was primarily adopted as a deforestation control measure together with the need for addressing the basic forest use rights of the local community. However, recently it has strived to incorporate a diverse set of conservation, socio-economic and political objectives (FAO, 2016).
\end{abstract}

In Nepal, the concept of CBFM begun with a focus on the environmental aspects of forest conservation

This article is published under the terms of the Creative Commons Attribution License 4.0 Author(s) retain the copyright of this article. Publication rights with Alkhaer Publications.

Published at: http://www.ijsciences.com/pub/issue/2017-03/

DOI: 10.18483/ijSci.1232; Online ISSN: 2305-3925; Print ISSN: 2410-4477 
along with satisfying the basic forest product needs of the local people. Later, it was successful in addressing many cross-cutting issues like institutional sustainability, gender mainstreaming, good governance, sustainable livelihood and so forth. Recently, the focus has also been on burning issues of climate change, payment for environmental services (PES) and forest-landscape management. Moreover, the management regime is now evolving as a complex environment-livelihood-policy nexus (Pokhrel et al., 2008).

Globally, Nepal appears to be at the forefront of CBFM practice (Ojha et al., 2007). In this connection, this review paper has tries to explore the current status of various community based forest management (CBFM) modalities in Nepal retrospectively with the experience from the last 3 decades of policy formulation and implementation. Moreover, this paper also strives to illustrate the lessons learned, related issues and the recent initiatives on CBFM practice in Nepal. This paper is expected benefit the policy makers and practitioners interested and/or involved in implementing community based forestry in their country.

\section{Evolution of CBFM in Nepal}

Looking back at the global history of evolution of community based forest management, a need for a paradigm shift in forest tenure arrangements including the devolution of forest management was imperative in order to tackle the large scale deforestation (White and Martin, 2002). Similarly, same things happened in Nepal, the rapid depletion in forest resources and acceleration of deforestation was out of control from the state government because of the negative perception of people towards the state forest, like "State forests are no one's forests" (Kanel, 2007). To overcome these issues policymakers realized the role of local community to protect the forest and started thinking over the devolution of the forest to the local community. To make the story more apparent the evolution history of community based forest management in Nepal can be described in three major phases i.e. i) before 1950 during Ranas'Oligarchy ${ }^{1}$, the rapid conversion of accessible forest land into agriculture land; ii) 1951-1975, after abolition of Ranas' it was centralized forest management regime; and, iii) 1976 onwards, a policy shift towards participatory forest management.

The Government of Nepal has included regulatory enforcement in its various policies, acts and

\footnotetext{
${ }^{1}$ Ranas' Oligarchy: hereditary dynasty of the Ranas in Nepal from 1846 to 1950 AD. Kings were powerless during this period.
}

regulations for sustained supply of forest products in the country. In this connection, the first formal policy and administration started in 1925 (Pokharel, 1998). The community based forest management consequently evolved with the various reforms in forest policies. The history of forest policy reform in Nepal dates back to 1957 when the first Private forest Nationalization Act was promulgated. Before 1957 most of the accessible forests were administrated as the private property and the forest were continuously depleted and the deforestation was accelerated, the forests were being managed in traditional ways by the elite people of feudal autocratic Rana regimes in Nepal (Gautam, 2006; Cited in Gurung et al., 2011). And, in the mountains and hills, Talukdars ${ }^{2}$ had the responsibility of regulating forest use, but there was hardly any restriction on forest product extraction for subsistence (Mathema et al., 1999). Ironically, the Private forest Nationalization Act 1957 was not able to restrain people from entering and extracting forest products; rather performed as an enabler for further deforestation. People were not responsible for the protection of the forest because they do not feel the ownership on forest. Therefore, by the experience of 1957-1975 the government realized that forests are difficult to protect and manage by the government solely.

Accordingly, after the realization of centralized forest management regime was excluding the use right of local people was the root cause of poor conservation outcomes; the policymakers were enforced to recognize the decentralized policy with wide peoples' role in forest management activities. The decentralized and participatory forest management regime was started with the formulation of National Forest Plan 1976 (MPFS, 1989). It recognized peoples' role in forest management activities. Furthermore, forest policy reforms were initiated by the revision of forest act 1978 which facilitate the decentralized forest management regime through Panchayat Forest (PF) and Panchayat Protected Forest (PPF) regulations under party-less Panchayat political system $^{3}$ at that time. The benefit sharing to the local Panchayat from PF and PPF was $100 \%$ and $40-75 \%$ of total income respectively. However, the peoples were not fully satisfied by the Panchayat Forest because of the limited security of traditional use rights, lack of freedom of local people in decision making, and an absence of mechanism that guarantees the anticipated benefits to local people.

\footnotetext{
${ }^{2}$ Talukdars: Village head man appointed by the Ranas during Rana's Oligarchy.

${ }^{3}$ Panchayat political system: A traditional, party-less, self governing local government consisting five local people as "Panch" (The literal meaning of "Panch" is five).
} 
Moreover, the village Panchayats were considered too big to manage 'communal' forests and therefore 'community forestry' evolved following the adoption of Master Plan for the Forestry Sector in 1989 as a policy mechanism to hand over forests to forest user groups. The Plan provided very important guidance for forestry sector which had focused on people's participation in forestry resource development, sustainable forest management and conservation by enhancing the legal framework.

The subsequent Forest Act of 1993 (MFSC, 1993) and Forest Regulation of 1995 (MFSC, 1995) made the Community Based Forestry program effective legally. Later, the Forest Policy of 2000 focused on community empowerment and institution building for forest management and community development. Initially, the focus of community based forestry program was on conservation and mainly focused on middle hills. Recently, the Ministry of Forest and Soil Conservation decreed the revised Forest Policy 2015 (MFSC, 2015) with focus on beyond the basic needs of forest products, programs like "Forestry for Prosperity", and green economy and green employment by scientific and economic management of forest resources in sustainable way. Moreover, it has kept keen concern about the climate change, environmental protection $\&$ biodiversity conservation. At present, community based forest management programs are prioritized in order to meet the national development goals.

\section{Community Based Forest Management Modalities in Nepal}

As it is mentioned before, Nepal has realized the community based forest management system as a viable instrument for the sustainable forest management through key participation of local people. Provided the existing favorable policy instruments and encouragement from government and stakeholders, the community based forest management is striving to achieve the sustainable development goals in Nepal.

There are mainly six different modalities of community based forest management in Nepal which vary with the context, objective and provisioned bundle of tenure rights. According to the recent Forest Policy of 2015, the six management modalities namely Community Forestry (CF), Leasehold Forest (LHF), Collaborative forest management (CFM), Buffer Zone Community Forestry (BZCF), protected forest $(\mathrm{PF})$ and Religious Forest $(\mathrm{RF})$ are prioritized to make them ecologically sound, economically viable and socially acceptable. According to the recent data altogether $38.5 \%$ of total forest land of the country that is 2.3 million hectare forest is being managed by more than 3.8 million households under the broad regime of community based forest management. This vast number of households benefited has also brought special attention on further development and expansion of community based forest management modalities in Nepal (Box-1).

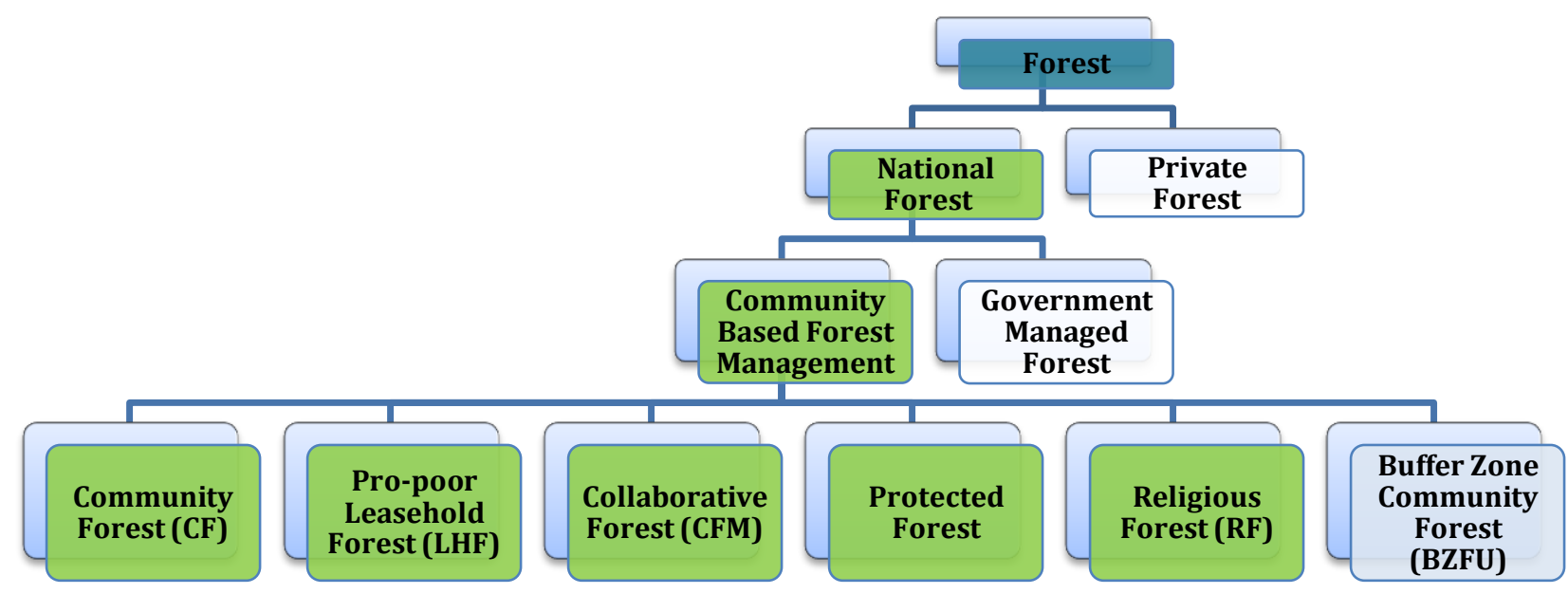

Figure 1: Community Based Forest Management modalities in Nepal 


\begin{tabular}{|l|} 
Box-1: Statistical Status of CBFM in Nepal \\
\hline SN
\end{tabular}

\section{* At the final stage of approval process}

Note: Forest of Nepal occupies $\mathbf{5 . 9 5}$ million hectares which is $\mathbf{4 0 . 3 6 \%}$ of country's land (DFRS, 2015). Therefore, the CBFM practice covers $\mathbf{3 8 . 5 \%}$ of total forest involving more than $\mathbf{3 . 8}$ million households. Source: Compiled from Hamro Ban 2015 (2072 B.S.), Department of Forest, Nepal

\subsection{Community Forest}

Community Forest (CF) in Nepal is defined as any national forest or part of National Forest that is handed over to a user group to develop, conserve and manage; extract, exploit, trade and/or distribute the forest products by fixing the prices independently, according to an approved operational plan (MFSC, 1993). In order to form a community forest users' group, first of all, a users' group must be established and get registered in the related District Forest Office together with their constitution. Only after the approval of constitution and Operational plan by the District Forest Officer, a community forest and its users' group is get formed. Further, the Forest Act (1993) states, "the concerned District Forest Officer will have the authority to hand over the national forest to a user group as a community forest."The users' group should comply with and act according to their constitution. Furthermore, the general assembly of user group has authority to select the executive committee and amend their constitution and forest operational plan. Albeit the technical assistance provided by the district forest office, it is a groups' own responsibility to prepare their operational plan.

Success stories over the past three decades more from all over the country have made it clear that community forestry is an excellent example of devolution where bundle of rights and obligations are handed over to the local community. However, the user group only has the use rights because the forest land still belongs to the state. Therefore users are not allowed to sell and hand over the forest land to others. In addition, almost all the benefits that come from the community forest belongs to the users, the benefit sharing mechanism inside group can be determined by the users themselves; however, there are some mandatory provisions determined by the Community forestry guidelines such as the allocation of $35 \%$ of the community forest income for the poverty alleviation programs inside their user group, and allocation of additional $25 \%$ of the income towards forest development activities (DOF, 2009). These provisions are laid to ensure equitable benefit sharing amongst the users and ensure the sustainable development of forest.

The community forestry in Nepal is not only the leading national program amongst various community based forest management modalities, but is also equally recognized and respected forest management strategy in the international arena. A recent survey carried out by Department of Forest Research and Survey estimated the Country's forest as 5.96 million ha which is $40.36 \%$ of the total area of the country (DFRS, 2015). On which, solely the Community Forest occupies 1.72 million hectare of forest land occupying $28.8 \%$ of total community forests area and involving 2.3 million households from all five physiographic region of the country (Box-1). The studies on effects of devolved forest management on resource conservation in Nepal have shown forest conservation and regeneration as a general picture (Chhetri et al., 2011; Bhattarai and Conway, 2008). Furthermore, community forestry also has enhanced the practice of leadership development, social inclusion and gender mainstreaming. About one thousand community forestry user groups are being handled by female only executive committee. This can be partly attributed to the fact that for all community forests $50 \%$ representation of women in executive committee is mandatory (DOF, 2009). Moreover, institutional development and good governance are also the achievements of the community forestry program in Nepal. Nevertheless, this couldn't have happened in a snap of the fingers. It encompasses a series of policy reforms with the lots of experiences and lesson learned. However, issues remain and there still is a lot of room for improvement. 


\subsection{Collaborative Forest Management}

The experience of implementing community forestry program has shown that it is successful in the hills, where forests and people exist together and where forests are only used for subsistence purposes. In the Terai, the southern plain of the country, however, the situation is quite different. Large blocks of highly valuable national forests are found in the Northern belt of Terai, while the majority of the population lives in the South. The people living in the South are traditional forest users. Since resource management has no 'one size fits all' solution, the community forestry model of the hills applied in the Terai has not been as successful in accommodating the use rights of these traditional users. Basically, the conventional community forests in Terai are neither able to fulfill the forest products needs of the traditional users, nor are able to assure a constant revenue flow to the Government. To address the prevailing issues of community forests in Terai, government of Nepal has been undertaking a series of reform efforts in order to sustainably manage the forests in the sub-region which ensures conservation, livelihood welfare of local forest dependent people and a constant revenue flow in part of the government. These efforts have yet to yield the fruits because of the centralized institutional structure of the forest management administration in Nepal (Ebregt et al., 2007; Cited in Poudyal, 2007). Therefore, considering the issues and experiences, the government of Nepal put forth a new participatory approach to forest management in 2000 called "Collaborative Forest management (CFM)" for the Terai, Churia and Inner-Terai sub-regions (MFSC, 2000). These were achieved through a revised Forest Policy of 2000. This revised policy includes the concept of Collaborative Forest Management (CFM) to initiate participatory management of CMFs especially large productive block forests in Terai and
Inner Terai. The CFM guideline of 2011 defines "Collaborative Forest Management as a means of sustainable forest management where forests are managed by government and stakeholders collaboratively according to the approved forest management plan to improve livelihoods, economic opportunities and other multipurpose benefits such as maintaining ecological balance" (MFSC, 2011). Now, Collaborative forest management modality is second largest community based forest management program in Nepal that covers more than 60 thousands hectares forest area benefiting over half a million households (Box: 1).

For the benefit sharing, total production of timber and fuel wood is divided in three parts proportionally. Among that $50 \%$ quantity of timber and fuel wood goes to User group, $10 \%$ goes to Local Government and $40 \%$ goes to Central Government (MFSC, 2016).The government can sell its own shares amount by auction system. Whereas, the CFM group have to give first priority for the fulfillment of internal demand of users and only the surplus amount of timber can be sold outside by auction system. Furthermore, the CFM user-group have to allocate $40 \%$ of its income in forest management activities, $10 \%$ for group administration and remaining 50\% for community development and poverty reduction programs. Now-a-days, CFM is a focal management modality for intensive forest management to fulfill the country's need for timber by implying particular silviculture system for the yield regulation. Both formally and colloquially, this intensive forest management strategy is termed "Scientific Forest Management" (MFSC, 2016).Owing to the resource, policy and technical (know-how) limitations, however, the strategy is still in its infancy and way far from perfect. 


\section{Box- 2: Overview of tenure arrangements for different CBFM modality in Nepal}

\section{Forest Management Modality}

i. Community Forest: part of the national forests handed over to forest user groups for development, conservation and utilization in the interest of the community

\section{ii. Collaborative Forests: National} forest manages in collaboration with local people, local government and Department of forests.

iii. Pro-poor leasehold forest: National forest handed over to a group of local poor HHs for mainly to improve their livelihood.

iv. Religious forest: National forests that have been entrusted to any religious entity, group or community.

v. Protected forest: National forests that has been declared protected considering their environmental, scientific and cultural importance

vi. Buffer zone (BZ) CF: This is the Forest outside the core area of National parks and wildlife reserves managed by local community as community forest.

\section{Tenure Arrangement}

- Tenure period is not limited by law; management is regulated usually by 5-10 years management plan after approval by District forest office

- Recognizes traditional use rights and access.

- Users have rights to make plan, fix rate and sell forest products

- Only the surplus forest product, after fulfilling the need of local user group, can be sold outside.

- Management Tenure is unlimited; management is defined through a 510 years Management plan.

- Benefit sharing: 50\% user group, $40 \%$ District forest office and $10 \%$ local government.

- It also includes the distant users

- User group have to satisfy the need of user group at first and surplus products can be sold outside.

- Tenure period is 40 years, can be extended for another 40 years.

- Use right only, land ownership remains with Government.

- Users are not allowed to harvest existing trees before hand over; however, they can harvest and sell any product planted by them.

- Only degraded forest land is handed over to the ultra poor household.

- Tenure is unlimited; management is defined through 5- year plan.

- Reorganization traditional use rights required.

- Sale of forest products for commercial purpose restricted.

- Forest is used for religious purpose only.

- Management is defined usually through 5-10 year plan.

- Limited user right is given to local community mainly focus on protection of special feature of that forest.

- Government and line agencies implement subsidy programs like alternative energy, support for private forest, eco-tourism development etc.

- Community can harvest and use their forest product for their own use only and there is no authority to sell timber in outsiders.

- 30 to 35 percentage of income of the National Park and Wildlife Reserves from tourism goes to the welfare of BZ management committee.

Source: Compiled from related acts, regulation and guidelines under Ministry of Forest and Soil Conservation, Nepal

\subsection{Pro-poor Leasehold Forest}

The Pro-poor Leasehold forestry program is mainly focused on to reduce the rural poverty by income generation activities and to improve the degraded hill forests. This modality of community based forest management was put forth in 1992 with the assistance of International Fund for Agricultural Development (IFAD) (DOF, 2014). In Nepal, Propoor Leasehold forestry program is a priority program because of its potentiality to reduce poverty as well as rehabilitate the degraded forest. Leasehold forest in reality is a small patch of degraded forest (5-
15 hectare in average) provided for lease by identified pro-poor households(in average 5-15 households) for 40 years in first time. The modality is legally backed by Forest Act of 1993 and Forest Regulation of 1995. In the leasehold forests, the users are allowed to grow cash crops, fruits trees and other non-timber forest products and extract fodder and grasses to support their livelihood. One-time establishments grant and continuous financial support is provided by the District Forest Office and District Livestock Services Office who are also the major district level stakeholders for this program. The 
ownership of the land and already existing matured trees (more than $30 \mathrm{~cm}$ diameter at breast height) belong to the government (MFSC, 19995). However, the newly grown trees and any other forest product belong to the user group. There is no royalty charged for the pro-poor leasehold forest during its entire lease period of 40 years. Meanwhile, the other kinds of leasehold forests leased to the forest base industries and private company for commercial purposes have to pay a stated royalty to the government in accordance to the law.

The pro-poor leasehold forestry program in Nepal has been evolving since its inception. During its initial phase, from 1992 to 2002, Hills Leasehold Forestry and Forage Development Program (HLFFDP) was implemented successfully in 10 districts. Subsequently, by the experience and learning form this program, it was further expanded to more districts under different names with key technical and financial assistance from several non/government organizations. Regardless of their names, all pro-poor leasehold forestry programs in all their manifestations had the same objectives of poverty reduction and pro-poor (alternative) income generation. One manifestation of the pro-poor leasehold forestry has been implemented in the community forests by identifying small group of propoor households and providing them some forest land and technical backup for their livelihood enhancement activities.

In 2015 , there were a total of 7,419 leasehold forests managing 42,735 hectares degraded forest-land and involving around 75,000 pro-poor families (DOF, 2015). Basically, the prime objective of this modality was to improve degraded forest land by improving the livelihood of poorest people through the wise use of forests. Along with this prime objective there are several other benefits of this program. As a result of the various capacity development programs including study tours provided by the different line agencies, it was evident that the awareness level, fund mobilization capacity, leadership development, institutional capacity development, gender awareness and the endowment of social capital amongst the beneficiary pro-poor users has significantly improved. The overall productivity of forest has equally increased (Kafle, 2015). To support the claim, a study conducted by Ohlar in 2000 found that the natural regeneration growth in leasehold forest was rapid, and the crown cover increased three folds in the leased forests. Similarly, the biodiversity of the forest has significantly increased because of the adoption of stall feeding system in livestock farming and zero grazing approach (NPC, 2005). However, the management modality has still some issues to be addressed such as the ownership of the previously existing trees, the continuity and expansion of this program in more districts, proper identification of pro-poor households to name few. In order to overcome these issues, key adjustments to the existing policy and formation and revision of relevant guidelines are imperative.

\subsection{Protected Forest}

In Nepal, Protected forest (PF) is a national forest declared by the Government as a protected forest under the provision of Forest Act of 1993, considering it to be of special environmental, scientific or cultural importance (MFSC, 1993). PF is rising as a feasible approach for managing the forests having special features. It is also one of the community based forest management modalities in Nepal that helps to conserve biodiversity, cultural value together with enhancing people's livelihood. However, the focus remains on the key features of that forest for which it could be declared as the protected forest. In Nepal, some of the protected forests provide linkage between different protected areas of Nepal and encompass biological corridors and bottlenecks. Likewise, other protected forests encompass some critically important features of archeological, cultural and tourism importance, and watershed conservation (Baral et al, 2016). Government of Nepal has already declared eight protected forests that cover 133,685 hectares of forest area and eight more protected forests are in process of declaring throughout the country (DOF, 2016).

The protected forests are broader in area and scope than other forest type. It may include community forest, leasehold forest and religious forest as management units. However, there is no any rigid structure or model for the involvement of local peoples in its management in prevailing forest act and regulation. However, in practice, PF are being managed by the Forest Management Council that creates room for local people's participation. That can be defined during the preparation of $\mathrm{PF}$ management plan and its management procedure. Aryal et al. (2012) has proposed a model for Barandabhar Protected Forest with similar Forest Management council and the involvement of all the stakeholders including the local community. Subsequently, other protected forests are also being managed with a similar model of council formation as displayed in Figure-2. The management Council serves an umbrella for other forest management units and users groups inside the declared protected forest area. 


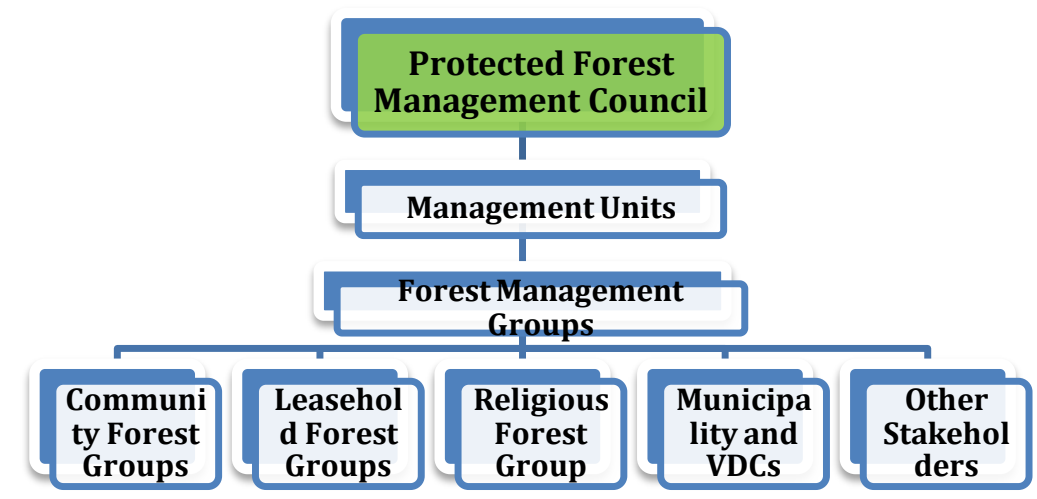

Figure 2: General model of Protected Forest Management Council

Studies show that this CBFM modality has positive impact on conservation of watershed, cultural, historical and archeological site as well as the biological diversity. Besides, it has also contributed to promote private forestry through nursery establishment and plantation programs. Together with the private forests, the protected forests have led to promotion of alternative energy program which has helped to reduce the pressure on other forested lands. Therefore, this modality is very important and it can be categorized as ecological forest that is being managed jointly with the local community. Even though in its initial phase, it seems like protected forests are over looked because of inadequate legal and policy support. For the better functioning of PF, there is an urgent need of clear policy instruments that should be prepared and enacted as soon as possible.

\subsection{Religious Forest}

Nepal's Forest Act 1993 has defined Religious Forest under the section-34 as a part of national forest handed over to any religious body, group or Community for its development, conservation and utilization. Generally, these forests exist around the temple or any other sacred religious places and have been registered as religious forest. The district forest officer has authority to handover such forest to the group or community after their formal application with a forest management plan. However, these kinds of forests are not for intensive management or commercial use. The focus remains on conservation for aesthetic or religious purpose. But, sometimes, non-commercial utilization of dead, dying and diseased trees are allowed. A prior approval should be taken from the concern district forest office for any kind of extraction to be made from religious forests. Having said that, these forests don't have major impact on the livelihood improvement of local communities, but enhance the aesthetic value of the religious palace and help protect the religious place from conspicuity and prying eyes of vandals. Altogether 36 religious forests are registered occupying 2,036 hectares area of National Forest (DOF, 2015).

\subsection{Buffer Zone Community Forest}

Buffer Zones in Nepal are the peripheral area of the national parks and wildlife reserves declared by the government under prevailing act. Legally, it also refers to the villages, settlements or hamlets set aside as buffer zone lying within the National Park or Reserve (MFSC, 1999). In other word, buffer zones can be defined as a sustainable development zones, co-managed by protected area authorities and local communities to ensure sustained flow of forest products to meet local needs and to enhance local livelihoods such that it ultimately reduces pressure on national parks and wildlife reserve (Sharma and Shaw 1996 ; Cited in Paudel et al., 2007) and the human wildlife conflict. Accordingly, the buffer zone community forests (BZCF) are the community forests within the buffer zone areas. They are also government forests handed over to the local communities for biodiversity conservation and fulfilling their needs of forest products at the same time. The legal policy instrument established specifically for the buffer zone management is the Buffer zone Management Rules of 1996, together with the Wildlife Conservation Act of 1973. The chief warden of national parks and wildlife reserve has the authority to approve the management plan of BZCF and handover such forest to the BZCF user group. There are 677 BZCFs that cover altogether 198,550 hectare of forest area benefiting around two third of a million households (DOF, 2015). Human wildlife conflict and its compensation, elite dominancy within group, and lack of proper back up are the major issues and gaps in Buffer zone community forestry programs.

\section{Issues and Lesson learn}

By the past experience it was learned that only single management modality is not enough to address the diverse needs of people in different physiographic regions of Nepal. While the successful 
implementation of Community forestry program was going on, the people far from the forest were not happy because there was no any accessible forest for them to fulfill their daily forest product needs. As a result, collaborative forest management came in to practice to address the needs of the distant users. Similarly, in most of Community forestry elite dominancy in decision making has led many poor and marginalized sections of the community fell disfranchised and as a consequence less motivated towards community forest management activities. In order to address the needs of the poor and the marginalized, Pro-poor Leasehold Forestry program was brought forward which has been doing really well with the livelihood of target communities as well as the forest and biodiversity conservation. Additionally, forest modalities such as religious forests and protected forests were developed with specific management objectives with comparatively lesser active involvement of local communities compared to other modalities, while still being significant on religious, cultural, scientific and biodiversity grounds. CBFM programs in Nepal have increased people's involvement in forest management, conservation awareness and their endowment of livelihood capital. It also has played crucial role in rehabilitation of degraded forests. The scenario has shown that CBFM practices has increased local job opportunity, improved yield, protected habitat of endangered and keystone species of flora and fauna as well as contributed to the overall welfare of forest dependent communities.

Despite the success stories, there are several issues that cannot be overlooked when it comes to community based forest management in Nepal. The inequitable benefit distribution is one of the several concerns. A number of studies have looked into distributional equity, suggesting that the poorest benefit the least from community forestry for a number of reasons. The poorest may be excluded from access to subsidized products and user rights through CF user groups due to high membership fees (Banjade et al., 2004). In some cases, primarily rich people benefit from the subsidized timber price because mainly rich can buy the timber. Whereas the pricing policy implies that little revenue is generated for redistribution to the poorest through the CFUG fund (Dhakal and Masuda, 2009). Elite dominancy in decision making process is still existing by which the voice of marginalized and disadvantage group is suppressed in various areas. Moreover, dual membership of community forest user group, boundary conflict, environmental negligence during construction of rural road and other infrastructures by the CFUG fund without environmental examination or requirements are the existing problems and issues in community forest of Nepal (Oli et al., 2014).
Community forests in buffer zone and protected forests also have issues of human wildlife conflict. Although the government has launched wildlife damage relief guideline, subsidy in not sufficient and getting process is tedious.

In order to realize the sustained yield, several CF and CFM modalities have started to practice scientific forest management, which is technical management with particular silviculture system. To prepare such management plan accurate information about the forest is needed and the prepared plans are the guidelines and source of information for the users to manage their forests technically. However, studies have shown most of the management plans of community forests have insufficient information for users to provide a complete guidance on scientific forest management (Rutt et al., 2014). . As a result, it has been hard to meet the target of sustain yield in such modalities. Finally, as the role of forests in combating human induced climate change and other environmental challenges has been better understood recently, viable policy measures to address such challenges are still lacking for the forestry sector as a whole in Nepal.

\section{Recent initiatives}

Given the issues, there have been attempts in part of government for to address those issues in order to realize the multifaceted goals of community based forest management. In 2012, Ministry of forest and soil conservation declared "Forestry for Prosperity" as the vision for forestry sector. It has mainly four pillars: sustainable and scientific forest management, sustainable use of resources, forestry sector governance and enabling environment. Following this initiative, forestry decade (2014-2024) program was kept in priority as a national campaign. Through this, intensive plantation, forest rehabilitation, urban forestry, and private forestry support program are being launched as package programs. Ultimately, most of them are based on people's participation. Moreover, national and regional workshops on Community Forestry, Pro-poor Forestry and other CBFM models have been conducted. It has created forum for sharing experience and raising the current issues for way out and policy reform. Similarly, the newly formulated Forest Policy 2015 has focused on an inclusive, decentralized, competitive and wellgoverned forestry sector in order to enhance equitable benefit sharing, steady income and sustainable livelihood opportunities through community based forestry.

Likewise, Forest Act of 1993 was amended in October 2016. It has given broader space for the community based forestry. It has made legal provision for the collaborative forest management 
and its benefit sharing mechanism and allocation of budget for the forest and social development activities. And, it has also provided clear provisions for implementing scientific forest management in some CBFM models. It also has granted community rights over ecosystem services such as ecotourism, hydrological system, biodiversity conservation and Carbon sequestration. Commercial management of $\mathrm{CF}$ is also permitted that was off the limits before. In the case of pro-poor leasehold forest, there is provision made for providing certain percentage of income from the sale of existing trees (for which government has a claim even though the forest was handed over to the local community as pro-poor leasehold forest) at the hand over time. Furthermore, Forestry Sector Strategy (2016-2025) was formulated in July 2016 by the Ministry of forest and soil conservation. It has also given priority to the CBFM by formulating strategic actions such as promotion of all types of CBFM modalities as priority subsector for Nepal, reflecting its important contribution to poverty reduction and its potential to enhance livelihood of people and economic development (MFSC, 2016a). It also has stressed on the promotion of Payment for Ecosystem services (PES) in all CBFM modalities as a key component for REDD+ programs.

\section{Concluding Remarks}

The CBFM concept in Nepal is not new; it has been practiced in different form from the ancient time. Nonetheless, the present concept and status of CBFM in Nepal was not designed at a single time, it is a result of past experience, research and lesson learned. By the past experiences it can be concluded that single type of CBFM model is not enough to address the varied need and interest of different category people from diverse locality; it can be changed or modified accordingly through the policy reforms. Although CBFM concept in the initial phase was focusing on the environmental aspects to conserve forests together with satisfying the basic needs of forest products of local people; but later it included many cross-cutting issues such as institutional sustainability, gender mainstreaming, good governance, livelihood improvement etc. Recently, it has focused on some additional issues like climate change, payment for environmental services and managing forests across the landscape; therefore it is moving toward the complex environmental policy (Pokhrel et al., 2008). On the basis of past history and learning Nepal has realized that the goal of sustainable forest management cannot be achieved solely. It is only possible by putting hands on hands with the local community, in the real sense; they are the real ancient users of the any kind of forests. For this, it must be focused on the livelihood improvement of the local people to increase the active participation. Finally, it is now widely recognized that secure tenure arrangements are one of the most important prerequisite for attaining sustainable forest management (FAO, 2011). Moreover, the present scenario has shown that CBFM practices has increased local job opportunity, improved yield, protected habitat of endangered and keystone species of flora and fauna as well as contributed to the overall welfare of forest dependent communities. Despite the success stories, there are still several issues that can be faced during the implementation and cannot be overlooked. Policies and legislations are not always perfect. By the past experience it was found that policies and legal arrangements should be improved with time on the basis of past learning. In the case of Nepal, the evidence and studies shows that legal arrangement have been done time to time, however many problems and issues can be seen again. Finally, we can say, facing issues, finding the solution and arranging the legal provisions to overcome those issues and then implementation and again facing another problems and issues is a common cycle.

Therefore, for the continuity and expansion of CBFM program issues and gaps should be addressed through the key adjustments to the existing policy and formation and revision of relevant guidelines are imperative on the basis of changing context and lesson learns. Moreover, as the role of forests in combating human induced climate change and other environmental challenges have been better understood recently, viable policy measures to address such challenges should be formed and linked with forestry sector as a whole in Nepal.

\section{Acknowledgements}

I would like to thank my co-authors for their continuous effort to prepare this paper. I would also like to convey my gratitude to the Department of Forest, Nepal for providing me required data and documents, APFNet and Beijing Forestry University, China for providing me favorable environment. Finally, I would like to acknowledge Pradeep Baral and Shanta Ram Baral for their valuable suggestions and comments on its draft.

\section{References}

1) Adhikari, B., Lovett, J.C., 2006. Transactions costs and community-based natural resource management in Nepal. Journal of Environmental Management 78, 5-15.

2) Aryal, A., Brunton, D., Pandi R., Shrestha, T.K., Lord, J., Koirala R.K., Thapa, Y.B., Adhikari, B., Ji, W., and Raubenheimer, D., 2012. Biological diversity and management regimes of the northern Barandabhar Forest Corridor: an essential habitat for ecological connectivity in Nepal. Tropical Conservation Science Vol. 5(1):38-49. Available online: www.tropicalconservationscience.org

3) Banjade, M.R., Luintel, H., Neupane, H.R., 2004. An action and Learning Process for Social Inclusion in Community Forestry. In: Kanel, K.R., Niraula, D.R., Mathema, P., 
Kandei, B.R., Sharma, A.R., Gautam, M. (Eds.), Twenty Five Years of Community Forestry. Proceeding of fourth National Community Forestry Workshop. Community Forestry Division, Department of Forest, Kathmandu, Nepal.

4) Bhattarai, K., Conway, D., 2008. Evaluating land use dynamics and forest cover change in Nepal's Bara district (1973-2003). Human Ecology 36, 81-95.

5) Baral, S.R. Sapkota, S. and Paudel, G., 2016. Forest Management Practices and Issues of Protected Forest in Nepal. Poster published in "First National Silviculture Workshop (19-21 February 2017).Silviculture Division, Department of Forest, Kathmandu, Nepal.

6) Chhetri, B.B.K., Lund, J.F. and Nielsen, O.J., 2011. The public finance potential of community forestry in Nepal. Ecological Economics (2011), doi:10.1016/j.ecolecon.2011.09.023

7) Dhakal, M., Masuda, M., 2009. Local pricing system of forest products and its relations to equitable benefit sharing and livelihood improvement in the lowland community forestry program in Nepal. Forest Policy and Economics 11, 221-229.

8) DFRS, 2015. State of Nepal's Forests. Forest Resource Assessment (FRA) Nepal, Department of Forest Research and Survey (DFRS). Kathmandu, Nepal.

9) DOF, 2009. Community Forestry Guideline 2009. Department of Forest, Babarmahal, Kathmandu, Nepal.

10) DOF, 2014. Workshop proceedings on "Leasehold Forestry: A New Dimension on Livelihoods" Regional Workshop on Pro-poor Leasehold Forestry 11-13, June, 2014, Kathmandu, Nepal. p-1.

11) DOF, 2015. Hamro Ban 2072 (Nepali Version).Annual Progress Report FY 2071/072 B.S. Departmanet of Forest, Kathmandu, Nepal. (P-75).www.dof.gov.np

12) DOF, 2016. Unpublished data taken from Forest Management Section on December 2106. Departmanet of Forest, Kathmandu, Nepal. website: www.dof.gov.np

13) Ebregt. A., Sah, R.N., Paudyal, D., Thapa, Y.B. and Siwakoti, R.S., 2007. Collaborative Forest Management in Nepal (Challenges and Prospects). BISEPT-ST, Central Support Unit, Kathmandu, Nepal.

14) FAO, 2010. Global Forest Resources Assessment 2010 main report. FAO Forestry Paper No. 163. Rome.

15) FAO, 2016. Forty years of community-based forestry: A review of its extent and effectiveness. FAO Forestry Paper No. 176. Rome.

16) Gautam, K.H., 2006. Forestry, politicians and power perspectives from Nepal's forest policy, Forest Policy Econ., $8,(\mathrm{P} 175-82)$

17) Gurung, A., Karki, R. and Bista, R., 2011. CommunityBased Forest Management in Nepal: Opportunities and Challenges. Resources and Environment. 2011; 1(1): (P 2631). DOI:10.5923/j.re.20110101.04

18) Kafle, M.R., 2015.Leasehold Forestry in Nepal: Policy, issues and way forward (Nepali Version). Hamro Ban 2015 (2072 B.S). Department of Forest, Kathmandu, Nepal. (P 5165)

19) Kanel, K.R., 2007, Economic Impact of Forest Policy Changes: A perspective from Nepal. The Initiation, 2007. SUFFREC, Kathmandu Forestry College, Kathmandu, Nepal. (P 36-42)

20) Maraseni, T.N., Neupane, P.R., Lopez-Casero, F. and Cadman, T., 2014. An assessment of the impact if REDD+ pilot project on community forests user groups and their community forests in Nepal. Journal of Environmental Management, Volume 136. (P 37-46)

21) MFSC, 1993. Forest Act 1993. Ministry of Forests and Soil Conservation, Government of Nepal.

22) MFSC, 1995. Forest Regulation 1995. Ministry of Forests and Soil Conservation, Government of Nepal.
23) MFSC, 1999. Buffer zone Management Guideline 1999 (2056 B.S.). Ministry of Forests and Soil Conservation, Government of Nepal.

24) MFSC, 2000. Forest Policy 2000. Ministry of Forests and Soil Conservation, Government of Nepal.

25) MFSC, 2011. Collaborative Forest Management Guideline 2011 (Nepali Version, 2068 B.S) Ministry of Forests and Soil Conservation, Government of Nepal

26) MFSC, 2015. Forest Policy 2015. Ministry of Forests and Soil Conservation, Government of Nepal.

27) MFSC, 2016. Forest Act 1993, $2^{\text {nd }}$ Amendment 2016. Ministry of Forests and Soil Conservation, Government of Nepal.

28) MFSC, 2016a. Forestry Sector Strategy 2016-2025, 2016 Ministry of Forests and Soil Conservation, Government of Nepal.

29) MPFS, 1989. Master Plan for Forestry Sector, 1989. Ministry of Forests and Soil Conservation, Government of Nepal.

30) NPC, 2005. Impact Evaluation of Hills Leasehold Forestry and Forage Development Project, 2005. National Planning Commission. Government of Nepal.

31) Ohler, 2000. Final Report. Impacts of leasehold forestry on Livelihoods and Forest Management. Technical Assistance Phase two to the Hills Leasehold Forestry and Forage Development Project (GCP/NEP/052/NET). FAO, Nepal.

32) Ojha, H.R., Timsina, N.P., Kumar C., Belcher, B., Banjade, M.R., 2007. Community-based Forest Management Programmes in Nepal: An Overview of Issues and Lessons. Journal of Forest and Livelihood 6(2) September, 2007, P.1-7.

33) Oli, B.N., 2014. Pro-poor leasehold forestry in Nepal: A new Dimension on Livelihoods. Regional Workshop on Pro-poor Leasehold Forestry 11-13 June, 2014. Kathmandu, Nepal. Workshop Proceedings. Department of Forest, Kathmandu, Nepal. ISBN : 978-9937-2-8514-8. (P 53-66)

34) Oli, B.N., Dangi, R.B., Sharma, A.R., Pokhrel, D.C. and Karna, A., 2014. Community Forest in Nepal: Learning, Challenges and Destination (Nepali Version). Sixth National Community forestry Workshop report 2014. Department of Forest, Kathmandu, Nepal. (P 15-26)

35) Poudel, M., 2007. Evaluating Collaborative Management of Forest from Rangapur CFM, Rautahat. Banko Janakari, 17(1) pp.32-38. Department of Forest Research and Survey, Kathmandu, Nepal.

36) Paudel, N.S., Budhathoki, P. and Sharma, U.R., 2007, Buffer Zones: New Frontiers for Participatory Conservation?, Journal of Forest and Livelihood 6(2) September, 2007, P.4453.

37) Pokharel, B.K., 1998. Foresters and Villagers in Contention and Compact: The case of Community Forestry in Nepal. Unpublished Ph.D. Thesis. University of East Anglia, Norwich, U.K.

38) Pokharel, B.K., Branney, P., Nurse, M. \& Malla, Y.B. 2008. Community forestry: conserving forests, sustaining livelihoods and strengthening democracy. In H.R. Ojha, N.P. Timsina, C. Kumar, M.R. Banjade \& B. Belcher, eds. Communities, forests and governance: policy and institutional innovations from Nepal. New Delhi, Adroit Publishers.

39) Roe, D., and Fred, N., 2009. The Origins and Evolution of Community Based Natural Resource Management in Africa. Community Management of Natural Resources in Africa: Impacts, Experiences and Future Directions, 2009: 2-12.

40) Rutt, R.L., Chhetri, B.B.K., Pokharel, R., Rayamajhi, S., Tiwari, K., Treue, T., 2014. The scientific framing of forestry decentralization in Nepal, Forest Policy and Economics (2014), http://dx.doi.org/10.1016/j.forpol.2014.06.005

41) WHITE, A. and MARTIN, A., 2002. Who owns the world's forests? Forest tenure and public forests in transition. Forest Trends, Washington, D.C. 